Science, Technology and Development 34 (3): 122-129, 2015

ISSN 0254-6418 / DOI: 10.3923/std.2015.122.129

(C) 2015 Pakistan Council for Science and Technology

\title{
Determination of Heavy Metals in Agricultural Soil Adjacent to Functional Brick Kilns: A Case Study of Rawalpindi
}

\author{
${ }^{1}$ Khanorangah Achakzai, ${ }^{2}$ Sofia Khalid and ${ }^{2}$ Aasma Bibi \\ ${ }^{1}$ Sardar Bahadur Khan Women's University, Quetta, Pakistan \\ ${ }^{2}$ Fatima Jinnah Women University, The Mall, Rawalpindi, Pakistan
}

\begin{abstract}
Brick making is one of the growing industry of Pakistan which had great contribution in the development of country. In order to meet the demands of urbanization the industry's production rate is also increasing. This has lead to the combustion of enormous amount of coal and other materials thus deteriorating the quality of environment. Brick kilns in developing countries are considered as one of the important source of pollution. Heavy metals are one of the reported pollutants from brick kilns and are highly persistent, non-biodegradable in nature and are serious threat to the environment. The aim of the current study was to assess the level of heavy metals in the soil and vegetation around three selected brick kilns sites in Rawalpindi. The study was conducted from October 2013 to May 2014. The concentration of heavy metals in the soil and plants were determined with standard protocols. The investigated concentration of heavy metals in plants and soils were compared with the WHO standards. It was found that the concentrations of all studied metals were above the permissible limits especially at agriculture soil located adjacent to brick kilns. However, at few sites the concentrations were found below the permissible limits. The results of study showed that brick kilns have great potential of deteriorating the quality of environment so, it is recommended that the monitoring of soil and plants around brick kilns should be carried out on regular basis in order to develop control measures to prevent the impacts of heavy metals pollution.
\end{abstract}

Key words: Brick kiln, heavy metals, permissible limits, WHO, pollutants

\section{INTRODUCTION}

Soil in any environment whether rural or urban is considered one of the crucial components, subjected to pollutants coming from different anthropogenic sources. The major anthropogenic sources include combustion of fuels in brick kilns, mining, smelting and municipal solid wastes. The outcome of these anthropogenic sources is release of heavy metals, $\mathrm{SO}_{\mathrm{x}}$. $\mathrm{NO}_{\mathrm{x}}$, VOCs and $\mathrm{CO}_{\mathrm{x}}$ in the environment (Ahmed and Erum, 2010; Resongles et al., 2014; An et al., 2014; Civan et al., 2015; Mahmoud and Abdel-Mohsein, 2015). The release of toxic heavy metals is of major concerns in the areas located adjacent to sources such as brick kilns.

Soil pollution due to heavy metals has got serious attention in developing countries due to peculiar nature of heavy metals Abril et al. (2014). The studies show that heavy metals have deleterious impacts on environment due to their persistent nature (Sherene, 2010; Mathur and Kumar, 2013; Waoo et al., 2014). Some of the heavy metals are mobile in nature which move from soil to plants and underground water circulating through entire food chain indirectly affecting the health of human (Blackman et al., 2006; Bigdeli and Seilsepour, 2008; Joshi and Kumar, 2011). The release of heavy metals from brick kilns have adverse effect on soil, plants and people residing near brick kilns especially women and elderly people are at greater risk from such pollutants. Agricultural soils may also become polluted and growth and yield of the crops is affected. Effects of toxic heavy metals on plants in developing countries have been reported by many researchers (Bhanarkar et al., 2002; Singh and Agrawal, 2007; Ismail et al., 2012; Ahmed et al., 2015).

Monitoring of environmental quality around brick kilns should be of prime importance. Regular monitoring can help to evaluate the extent or trend of pollution and can also suggest some controlling measures as well as possible remediation.

Urbanization is one of the major factor in the development of country. In developing countries especially Pakistan with increasing speed of population the rate of urbanization is also increasing. In order to meet the demand of construction the number of brick kilns is 
also increasing in rural and outskrits of major urban areas. Million tons of coal is being used annually for the production of billions of bricks (Skinder et al., 2014). The brick sector of Pakistan is based on traditional Bull's Trench Kiln (BTK), contributing about $8 \%$ of global bricks production, producing more than 100 billion of bricks per year (Baum, 2010). It is seen that these brick kilns mostly use low cost waste material as source of fuel. The design of kilns, fuel characteristics and lack of complete combustion as well as no emission control devices contribute to the release of various contaminants and high concentration of pollutants in the form of flue gases (Bhanarkar et al., 2002; Blackman et al., 2006). The network of brick kilns in Pakistan is widely distributed in both urban and rural areas. there are about7000 brick kilns operating units in all over Pakistan, out of which 5000 brick kilns were only reported from Punjab (Bales, 2012) Less investment, availability of clay and water in the proximity of source and availability of labour are the main features that account for greater number of kilns in Punjab (Eswaran et al., 1993). Studies regarding the impacts of this main source of pollution on environment in Pakistan are not very common. Few studies were conducted in Peshawar (KPK, Province of Pakistan) in order to assess the impacts of brick kilns on soil and plants of surrounding areas (Ahmad et al., 2012; Ismail et al., 2012; Jan et al., 2014), but no study to our knowledge describes the situation in Rawapindi. The current investigation reports the results from one year study conducted in three brick kilns localities of Rawalpindi The objective of the study was to investigate the impacts of heavy metals pollution on the surrounding soil and plants.

\section{MATERIALS AND METHOD}

Description of the study site: Three brick kilns sites (Dhoke Syedan, Sihal and Chakri Road Rawalpindi) were selected for the current study. Brick kilns were selected on the basis of production capacity, functionality and nearness to the agricultural land. The details of selected sites in Rawalpindi are given below:

- Dhoke Syedan was taken as site 1 , where cluster of brick kilns were at distance of 500-600 m away from each other. They were about 15 in number, all in working condition. The design of all kilns was Bull's trench type that operates throughout the year

- One kiln was selected at Sihal Rawalpindi (site 2), with good production capacity. The design of kiln was traditional Bull trench type chimney with height of about $7 \mathrm{~m}$ without roof

- The other kiln was selected at Chakri (site 3) surrounded by agricultural land. Crops like wheat and mustard were growing in the vicinity of kilns. These crops were present at a distance of $200 \mathrm{~m}$ in West and North direction of brick kiln (Fig. 1)

Soil sampling and pretreatment of soil samples: Soil sampling was carried out in four directions (North, East, West and South), with increasing distance of 100, 300 and $500 \mathrm{~m}$ away from brick kilns at all three study sites. At all sampling points the soil samples were taken at the depth of 0-15 cm and composite sample was made to assess the cumulative impacts of brick kilns pollution. Pretreatment of soil samples was carried out by following Ishaq et al. (2010).

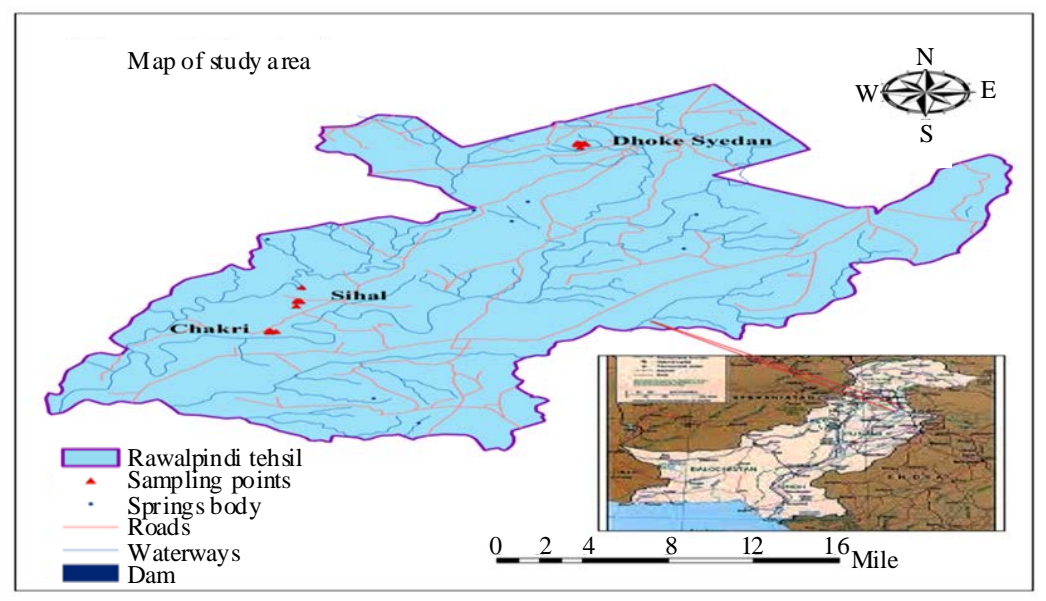

Fig. 1: Map of the study area 
Sci. Technol. Dev., 34 (3): 122-129, 2015

Acid digestion of soil samples: One gram of soil sample was taken in beaker and $12 \mathrm{~mL}\left(9 \mathrm{~mL} \mathrm{HCL}+3 \mathrm{~mL} \mathrm{HNO}_{3}\right)$ of aqua regia was added. Beaker was covered with watch glass and heated on hot plate at medium heat for $2 \mathrm{~h}$. The suspension was then allowed to cool and filtered through Whatman No. 42 filter paper. Leaching was done with distilled water and the volume was made up to $50 \mathrm{~mL}$. Heavy metals were analyzed through atomic absorption spectrophotometer (AAS model 220 Spectra AA Varian).

Plants sampling and pretreatment of plant samples: With increasing distance irrespective of direction, plants were collected. Plants were not available at all direction due to operational activities of brick kilns. The collected plants samples were immediately brought to the laboratory and were washed with distilled water. Pretreatment was carried out by using the methods of Ishaq et al. (2010).
Acid digestion of plant samples: The $0.5 \mathrm{~g}$ of crushed plant powder sample containing all plants parts such as roots, stem and leaves were taken in beaker and $12 \mathrm{~mL}\left(9 \mathrm{~mL} \mathrm{HCL}+3 \mathrm{~mL} \mathrm{HNO}_{3}\right)$ of aqua regia was added. Beaker was covered with watch glass and heated on hot plate at $80^{\circ} \mathrm{C}$ for $2 \mathrm{~h}$. The prepared suspension was allowed to cool and filtered through Whatman No. 42 filter paper. Leaching was done with distilled water and the volume was made up to $50 \mathrm{~mL}$. The digested plant samples were analyzed for $\mathrm{Cd}, \mathrm{Zn}, \mathrm{Pb}, \mathrm{Cu}$ and Ni with help of atomic spectrophotometer (AAS model 220 Spectra AA Varian).

\section{RESULTS AND DISCUSSION}

Heavy metals in soil samples: The average metal concentrations over a year showed a diverse pattern of distribution (Table 1 ). The concentrations of metals were

Table 1: Mean concentration ( $\mathrm{mg} \mathrm{kg}^{-1}$ ) and \pm SD of heavy metals at site 1-3

\begin{tabular}{|c|c|c|c|c|c|c|}
\hline \multirow[b]{2}{*}{ Direction } & \multirow[b]{2}{*}{ Distance (m) } & \multicolumn{5}{|c|}{ Heavy metals (mg kg ${ }^{-1}$ ) } \\
\hline & & $\mathrm{Zn}$ & $\mathrm{Ni}$ & $\mathrm{Cu}$ & $\mathrm{Pb}$ & $\mathrm{Cd}$ \\
\hline \multicolumn{7}{|l|}{ Site 1 } \\
\hline \multirow[t]{3}{*}{ North } & 100 & $176.7 \pm 0.30$ & $52.5 \pm 0.09$ & $76.8 \pm 0.04$ & $181.2 \pm 0.13$ & $14.0 \pm 0.03$ \\
\hline & 300 & $176.2 \pm 0.10$ & $96.9 \pm 0.30$ & $127.9 \pm 0.08$ & $156.5 \pm 0.11$ & $31.2 \pm 0.06$ \\
\hline & 500 & $211.9 \pm 0.11$ & $106.8 \pm 0.35$ & $141.9 \pm 0.13$ & $221.9 \pm 0.29$ & $24.6 \pm 0.04$ \\
\hline \multirow[t]{3}{*}{ South } & 100 & $217.9 \pm 0.22$ & $62.1 \pm 0.11$ & $146.5 \pm 0.07$ & $149.8 \pm 0.13$ & $17.1 \pm 0.03$ \\
\hline & 300 & $199.5 \pm 0.13$ & $62.9 \pm 0.14$ & $132.3 \pm 0.06$ & $168.6 \pm 0.14$ & $28.7 \pm 0.05$ \\
\hline & 500 & $209.9 \pm 0.13$ & $41.0 \pm 0.06$ & $99.8 \pm 0.05$ & $192.3 \pm 0.20$ & $28.1 \pm 0.03$ \\
\hline \multirow[t]{3}{*}{ East } & 100 & $188.9 \pm 0.16$ & $51.6 \pm 0.12$ & $131.3 \pm 0.13$ & $218.4 \pm 0.30$ & $10.2 \pm 0.01$ \\
\hline & 300 & $242.9 \pm 0.24$ & $64.1 \pm 0.14$ & $164.0 \pm 0.19$ & $220.1 \pm 0.17$ & $27.4 \pm 0.04$ \\
\hline & 500 & $231.7 \pm 0.15$ & $44.6 \pm 0.06$ & $97.3 \pm 0.06$ & $143.4 \pm 0.22$ & $31.8 \pm 0.03$ \\
\hline \multirow[t]{3}{*}{ West } & 100 & $220.8 \pm 0.11$ & $94.1 \pm 0.09$ & $114.3 \pm 0.04$ & $132.7 \pm 0.14$ & $24.6 \pm 0.04$ \\
\hline & 300 & $206.7 \pm 0.41$ & $62.1 \pm 0.07$ & $96.9 \pm 0.04$ & $186.7 \pm 0.13$ & $24.6 \pm 0.04$ \\
\hline & 500 & $212.8 \pm 0.30$ & $43.8 \pm 0.07$ & $79.5 \pm 0.02$ & $221.9 \pm 0.31$ & $11.1 \pm 0.01$ \\
\hline \multicolumn{7}{|l|}{ Site 2} \\
\hline \multirow[t]{3}{*}{ North } & 100 & $249.60 \pm 0.18$ & $260.7 \pm 0.20$ & $137.3 \pm 0.06$ & $213.1 \pm 0.22$ & $22.7 \pm 0.03$ \\
\hline & 300 & $312.30 \pm 0.38$ & $301.2 \pm 0.34$ & $231.8 \pm 0.27$ & $267.25 \pm 0.16$ & $14.4 \pm 0.02$ \\
\hline & 500 & $311.30 \pm 0.37$ & $276.7 \pm 0.23$ & $172.8 \pm 0.21$ & $226.4 \pm 0.06$ & $24.1 \pm 0.04$ \\
\hline \multirow[t]{3}{*}{ South } & 100 & $295.60 \pm 0.57$ & $206.8 \pm 0.21$ & $178.4 \pm 0.157$ & $198.9 \pm 0.08$ & $38.7 \pm 0.06$ \\
\hline & 300 & $342.30 \pm 0.52$ & $217.4 \pm 0.21$ & $129.6 \pm 0.08$ & $188.7 \pm 0.07$ & $171.6 \pm 0.02$ \\
\hline & 500 & $224.80 \pm 0.22$ & $156.7 \pm 0.27$ & $120.0 \pm 0.12$ & $181.7 \pm 0.06$ & $43.3 \pm 0.05$ \\
\hline \multirow[t]{3}{*}{ East } & 100 & $171.70 \pm 0.15$ & $186.7 \pm 0.14$ & $91.1 \pm 0.06$ & $222.8 \pm 0.10$ & $6.7 \pm 0.07$ \\
\hline & 300 & $221.70 \pm 0.32$ & $207.8 \pm 0.32$ & $502.5 \pm 0.08$ & $177.8 \pm 0.08$ & $34.6 \pm 0.03$ \\
\hline & 500 & $231.70 \pm 0.33$ & $197.3 \pm 0.23$ & $119.8 \pm 0.09$ & $181.7 \pm 0.06$ & $38.3 \pm 0.04$ \\
\hline \multirow[t]{3}{*}{ West } & 100 & $246.15 \pm 0.31$ & $193.4 \pm 0.25$ & $123.1 \pm 0.06$ & $227.8 \pm 0.14$ & $24.1 \pm 0.03$ \\
\hline & 300 & $20.80 \pm 0.23$ & $195.8 \pm 0.21$ & $149.2 \pm 0.12$ & $217.8 \pm 0.10$ & $20.8 \pm 0.03$ \\
\hline & 500 & $20.70 \pm 0.17$ & $24.5 \pm 0.251$ & $107.3 \pm 0.03$ & $196.15 \pm 0.1$ & $10.6 \pm 0.008$ \\
\hline \multicolumn{7}{|l|}{ Site 3} \\
\hline \multirow[t]{3}{*}{ North } & 100 & $256.2 \pm 0.12$ & $87.2 \pm 0.112$ & $122.1 \pm 0.03$ & $321.2 \pm 0.23$ & $38.4 \pm 0.04$ \\
\hline & 300 & $351.2 \pm 0.34$ & $111.7 \pm 0.15$ & $131.7 \pm 0.08$ & $167.8 \pm 0.08$ & $39.1 \pm 0.06$ \\
\hline & 500 & $311.7 \pm 0.34$ & $186.2 \pm 0.44$ & $106.7 \pm 0.05$ & $292.3 \pm 0.10$ & $15.8 \pm 0.01$ \\
\hline \multirow[t]{3}{*}{ South } & 100 & $376.2 \pm 0.35$ & $66.7 \pm 0.06$ & $126.1 \pm 0.01$ & $251.2 \pm 0.12$ & $8.2 \pm 0.005$ \\
\hline & 300 & $351.2 \pm 0.75$ & $83.1 \pm 0.10$ & $96.2 \pm 0.06$ & $212.3 \pm 0.14$ & $25.7 \pm 0.04$ \\
\hline & 500 & $256.7 \pm 0.19$ & $78.2 \pm 0.079$ & $117.3 \pm 0.07$ & $282.2 \pm 0.18$ & $44.1 \pm 0.08$ \\
\hline \multirow[t]{3}{*}{ East } & 100 & $256.2 \pm 0.18$ & $55.2 \pm 0.066$ & $110.9 \pm 0.04$ & $134.1 \pm 0.06$ & $29.7 \pm 0.04$ \\
\hline & 300 & $226.7 \pm 0.30$ & $71.1 \pm 0.09$ & $85.2 \pm 0.04$ & $126.2 \pm 0.09$ & $18.9 \pm 0.03$ \\
\hline & 500 & $276.2 \pm 0 / 40$ & $99.6 \pm 0.12$ & $116.6 \pm 0.06$ & $136.2 \pm 0.06$ & $9.2 \pm 0.05$ \\
\hline \multirow[t]{3}{*}{ West } & 100 & $256.2 \pm 0.25$ & $48.7 \pm 0.06$ & $93.7 \pm 0.03$ & $141.2 \pm 0.07$ & $21.6 \pm 0.03$ \\
\hline & 300 & $246.7 \pm 0.28$ & $51.1 \pm 0.06$ & $134.9 \pm 0.12$ & $191.0 \pm 0.11$ & $29.1 \pm 0.04$ \\
\hline & 500 & $281.7 \pm 0.27$ & $67.3 \pm 0.11$ & $78.00 \pm 0.05$ & $186.2 \pm 0.06$ & $8.1 \pm 0.003$ \\
\hline
\end{tabular}


found in order of $\mathrm{Zn}<\mathrm{Pb}<\mathrm{Ni}<\mathrm{Cu}<\mathrm{Cd}$ at all three study sites. The variations were seen in the concentration of all metals with respect to direction and distance. The difference in the concentration of metals with distance might be attributed to the fallout of pollutants a few meters away from the source depending upon the direction and velocity of wind. The results are also supported by Ismail et al. (2012), where they also noticed variations of $\mathrm{Cd}$ and $\mathrm{Cr}$ concentration with distance from brick kilns. When the concentrations of studied metals were compared with WHO standards it was found above the permissible limits. The high concentration of heavy metals in the soil of study site may be due to the burning of coal and low quality fuel like tyres, rubbers and other waste in non scientific ways. The burning of such fuels add a high load of various pollutants into surrounding environments. Comparatively greater concentrations of $\mathrm{Zn}$ were found in soil at the study sites and this might be ascribed to the application of fertilizers and pesticides. Zinc is also the main constituent of ash coming from brick kilns combustion activities (Sharma et al., 2007). The presence of $\mathrm{Pb}$ may be due to the burning of tyres during the baking of bricks. The variation in the concentration of heavy metals could be ascribed by number of factors i.e., physiochemical properties of soil, atmospheric deposition of heavy metals influenced by environmental conditions such as temperature, moisture, wind velocity (Sharma et al., 2009). In the current study, the $\mathrm{pH}$ of the
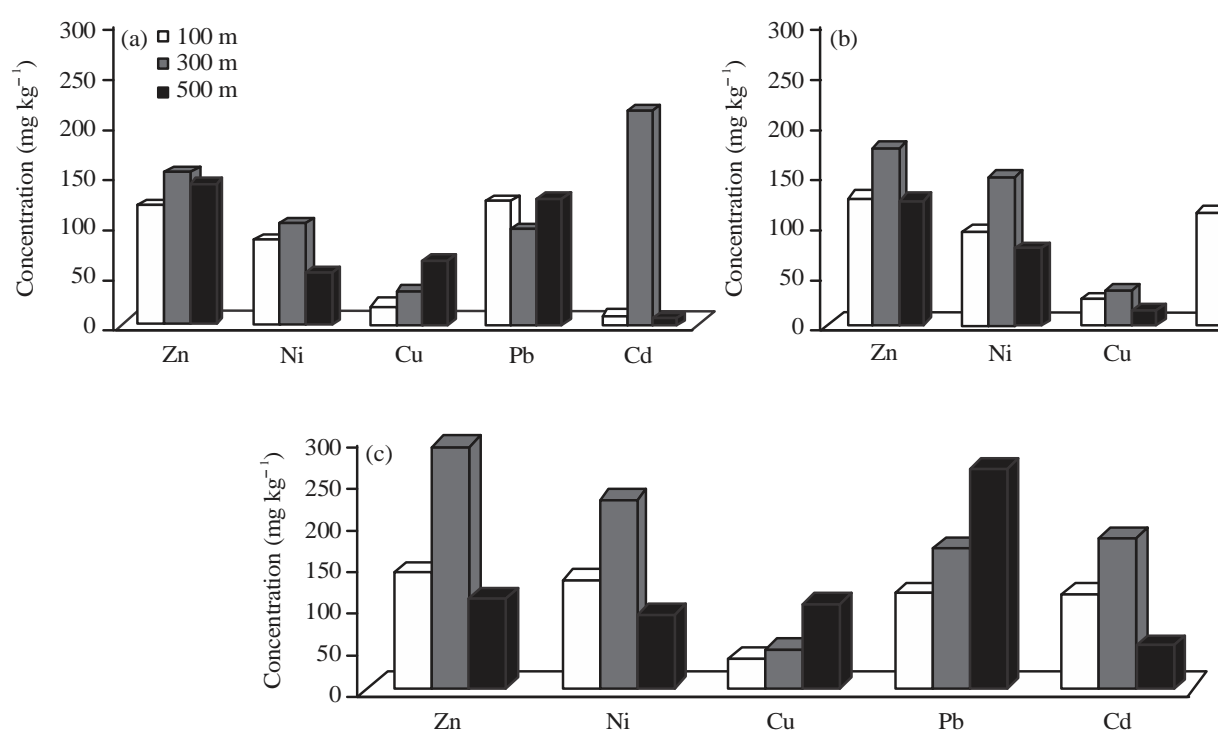

Fig. 2(a-c): Mean concentration of heavy metals in Calotropis procera at (a) Site 1, (b) Site (2) and (c) Site 3 soil ranged from slightly acidic to alkaline, the texture of the soil was found to be silt loam and generally these types of soils have the ability to retain moderate amount of organic matter (Tammeorg et al., 2014).

\section{Heavy metals concentration in selected plant species:}

The concentration of all metals in plants showed inconsistent trend at all three sites. The result obtained from the study showed that heavy metals concentration varied among the selected species. The concentration of heavy metals in the plants showed variation with distance supporting the fact that dispersion of heavy metals is dependent on the velocity of the wind which falls some meter away from the source. Similar results were obtained by Fatima (2011), where variations in chlorophyll content of plants was reported with increasing distance from brick kilns. Some other studies have also showed increasing concentrations of heavy metals in agriculture soil and plants with distance from pollution source (Tahar and Keltoum, 2011). The concentration of all detected metals were found above the permissible limits of WHO. The higher concentration of heavy metals in studied plants might be due to the aerial deposition of ash and dust particles produced during the combustion of various fuels (Wang et al., 2003). Plants takes different metals through roots and also through stomatal opening, these toxic metals get dissolved in the cell sap and circulate through entire plant (Meagher, 2000). Other

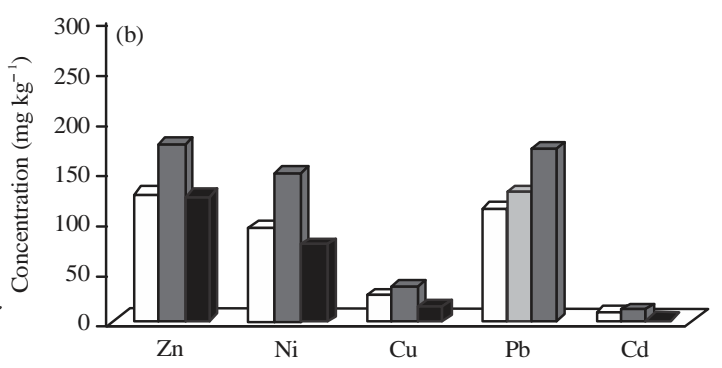



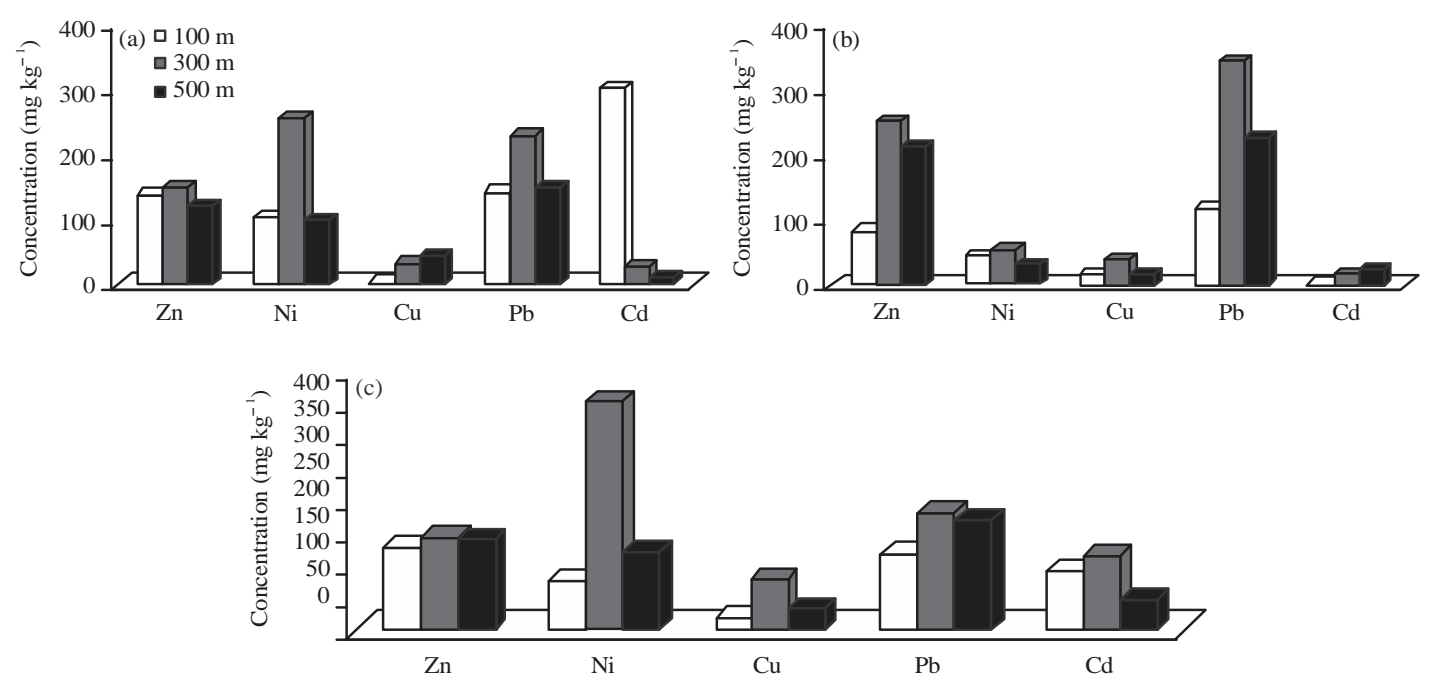

Fig. 3(a-c): Mean concentration of heavy metals at Datura inoxia at study (a) Site 1, (b) Site (2) and (c) Site 3
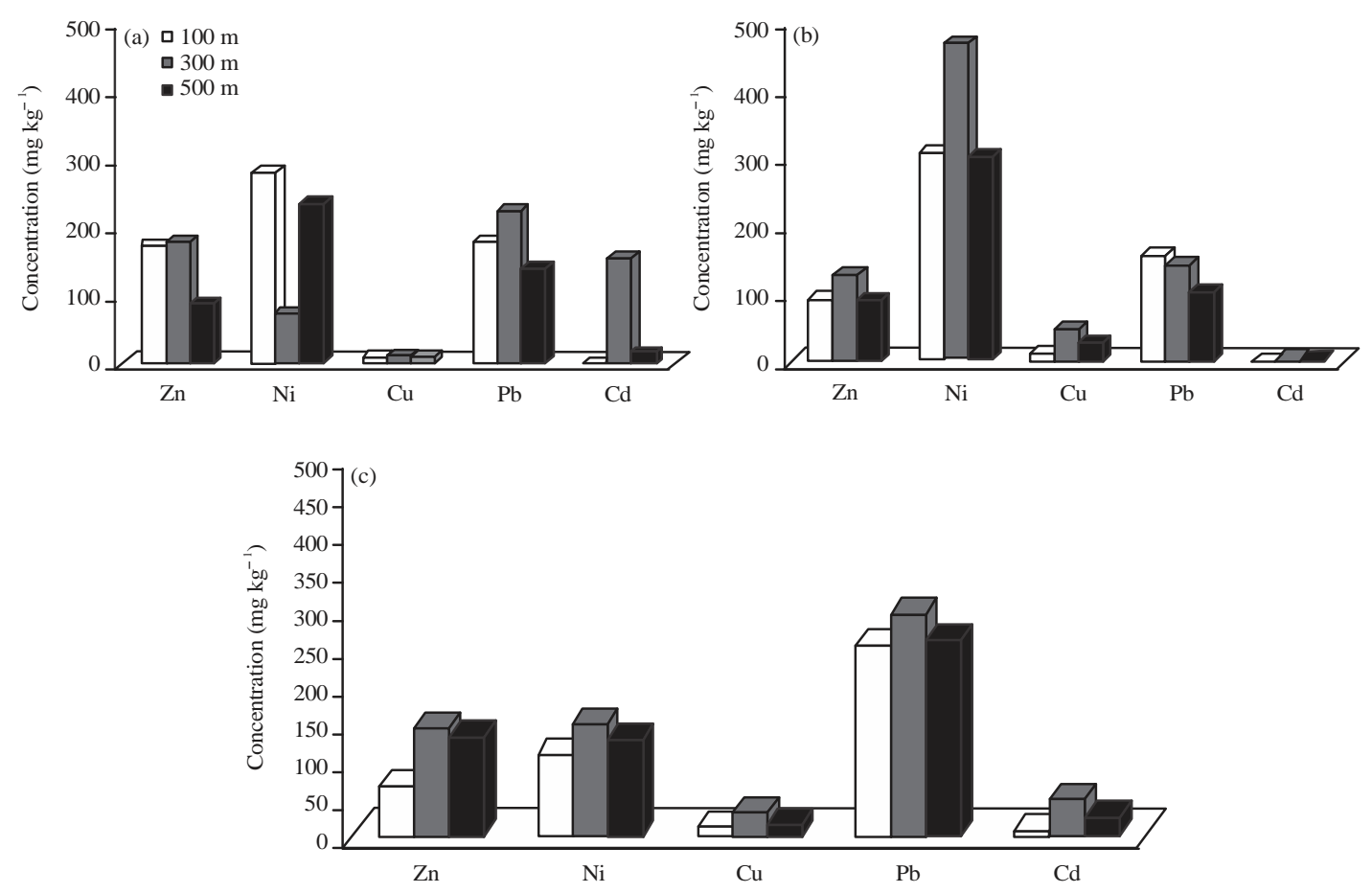

Fig. 4(a-c): Mean concentration of heavy metals in Triticum aestivum at (a) Site 1, (b) Site (2) and (c) Site 3

possible reasons of heavy metals contamination in plants may be by the application of fertilizer and pesticides in agriculture soil (Herawati et al., 2000). Difference in the metals concentration found in the selected plants species of the current study could be due to various factors e.g. the growing environment $(\mathrm{pH}$, temperature, soil aeration), the types of plants, size and root system the availability of elements to plant in the soil solution or foliar deposits, leaves morphology, soil moisture contents (Nagajyoti et al., 2010). The studied plants species were determined with different accumulation power which can be used positively as phytoremediator of heavy metals. Ample literature exists in which plants were used for remediation of different metals (Wani et al., 2012). Results are presented in the Fig. 2-5. 

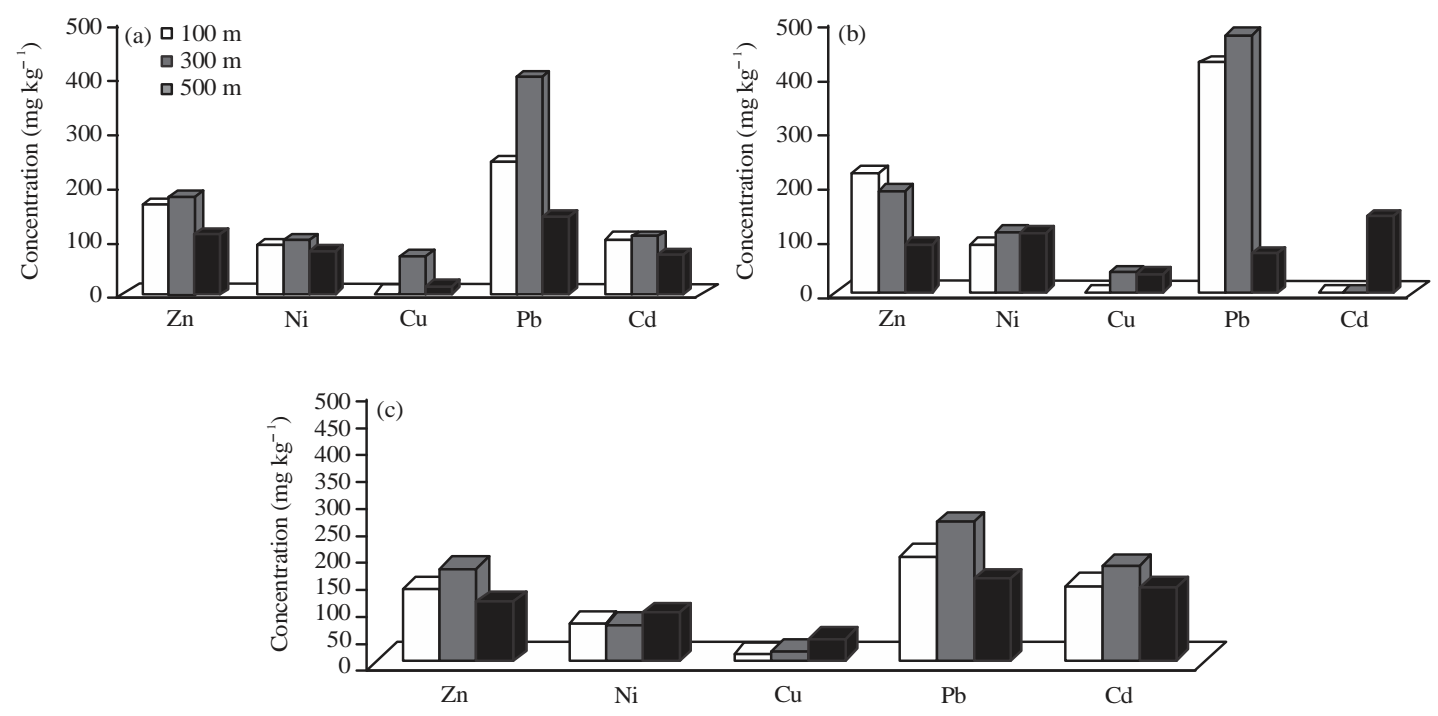

Fig. 5(a-c): Mean concentration of heavy metals Brassica compestris at (a) Site 1, (b) Site (2) and (c) Site 3

\section{CONCLUSION}

Brick kilns industry is considered as one of the main source of pollutants adding a lot to the environment in the form of particulate and other air pollutants. In the current study, the accumulation of heavy metals in the indigenous soil and plants were analyzed. It was determined that brick kilns industry was found a potential source of pollution in terms of heavy metals contamination.

The concentration of investigated heavy metals ( $\mathrm{Zn}, \mathrm{Ni}, \mathrm{Cd}, \mathrm{Cu}, \mathrm{Pb}$ ) compared to the WHO standard were found above the permissible limits in indigenous soil and plants. The high levels of metals concentration showed that this area has been affected by activities of brick kilns resulting in high metals contents as compared to their background levels. This higher concentration of metals investigated in both soil and plants are great risk of health not only for those people living in the vicinity of brick kilns and also for those depending on crops such as wheat and mustard as staple food. It is suggested from the results of current study that proper monitoring of this source of pollution should be carried out regularly in order to prevent the devastating impacts of pollution. The overall impacts of this industry could also be investigated by analyzing air by the study of various gaseous pollutants in order to determine the accumulative effects on the surrounding indigenous soil and biota.

\section{REFERENCES}

Abril, G.A., E.D. Wannaz, A.C. Mateos, R. Invernizzi, R.R. Pla and M.L. Pignata, 2014. Characterization of atmospheric emission sources of heavy metals and trace elements through a local-scale monitoring network using T. capillaris. Ecol. Indic., 40: 153-161.

Ahmad, M.N., L.J.L. van den Berg, H.U. Shah, T. Masood, P. Buker, L. Emberson and M. Ashmore, 2012. Hydrogen fluoride damage to vegetation from peri-urban brick kilns in Asia: A growing but unrecognised problem? Environ. Pollution, 162: 319-324.

Ahmed, S. and S. Erum, 2010. Integrated assessment of heavy metals pollution along motorway M-2. Soil Environ., 29: 110-116.

Ahmed, W., M. Ahmad, A. Rauf, F. Shah and S. Khan et al., 2015. Evaluations of some trace metal levels from the leaves of Salix nigra in Hayatabad industrial estate Peshawar, Khyber Pakhtunkhwa Pakistan. Am. J. Biomed. Life Sci., 3: 21-24.

An, J., B. Zhu, H. Wang, Y. Li, X. Lin and H. Yang, 2014. Characteristics and source apportionment of VOCs measured in an industrial area of Nanjing, Yangtze River Delta, China. Atmos. Environ., 97: 206-214.

Bales, K., 2012. Disposable People: New Slavery in the Global Economy. University of California Press, California, UK., ISBN-13: 978-0520272910, Pages: 336. 
Baum, E., 2010. Black carbon from brick kilns. Presentation for Clean Air Task Force, April 7, 2010. http://www.catf.us/resources/presentations/files/Bla ck_Carbon_from_Brick_Kilns.pdf.

Bhanarkar, A.D., D.G. Gajghate and M.Z. Hasan, 2002. Assessment of air pollution from small scale industry. Environ. Monit. Assessement, 80: $125-133$.

Bigdeli, M. and M. Seilsepour, 2008. Investigation of metals accumulation in some vegetables irrigated with waste water in Shahre Rey-Iran and toxicological implications. Am. Eurasian J. Agric. Environ. Sci., 4: 86-92.

Blackman, A., J.S. Shih, D. Evans, M. Batz, S. Newbold and J. Cook, 2006. The benefits and costs of informal sector pollution control: Mexican Brick kilns. Environ. Dev. Econ., 11: 603-627.

Civan, M.Y., T. Elbir, R. Seyfioglu, O.O. Kuntasal and A. Bayram et al., 2015. Spatial and temporal variations in atmospheric VOCs, $\mathrm{NO}_{2}, \mathrm{SO}_{2}$ and $\mathrm{O}_{3}$ concentrations at a heavily industrialized region in Western Turkey and assessment of the carcinogenic risk levels of benzene. Atmos. Environ., 103: 102-113.

Eswaran, H., S.M. Virmani and L.D. Spivey, 1993. Sustainable Agriculture in Developing Countries: Constraints, Challenges and Choices. In: Technologies for Sustainable Agriculture in the Tropics: Proceedings of Two International Symposia held in San Antonia, TX and Denver, CO., 1990 and 1991 Respectively, Ragland, J. and R. Lal (Eds.). American Society of Agronomy, New York, USA., pp: 7-24.

Fatima, I., 2011. Impact of brick kiln emissions on the ambient air quality and vegetation: A case study of district Budgam. M.Phil Thesis, University of Kashmir, India.

Herawati, N., S. Suzuki, K. Hayashi, I.F. Rivai and H. Koyama, 2000. Cadmium, copper and zinc levels in rice and soil of Japan, Indonesia and China by soil type. Bull. Environ. Contam. Toxicol., 64: 33-39.

Ishaq, M., M.A. Khan, A.F. Jan and I. Ahmad, 2010. Heavy metals in brick kiln located area using atomic Absorption spectrophotometer: A case study from the city of Peshawar, Pakistan. Environ. Monit. Assess., 166: 409-420.

Ismail, M., D. Muhammad, F.U. Khan, F. Munsif, T. Ahmad, S. Ali and M. Ahmad, 2012. Effect of brick kilns: Emissions on heavy metal (Cd and $\mathrm{Cr}$ ) content of contiguous soil and plants. Sarhad J. Agric., 28: 165-170.
Jan, F.A., S. Khan, M. Ishaq, M. Naeem, I. Ahmad and S. Hussain, 2014. Brick kiln exhaust as a source of Polycyclic Aromatic Hydrocarbons (PAHs) in the surrounding soil and plants: A case study from the city of Peshawar, Pakistan. Arab. J. Geosci., 7: 13-19.

Joshi, N. and A. Kumar, 2011. Physico-chemical analysis of soil and industrial effluents of sanganer region of Jaipur Rajasthan. Res. J. Agric. Sci., 2: 354-356.

Mahmoud, M.A.M. and H.S. Abdel-Mohsein, 2015. Health risk assessment of heavy metals for Egyptian population via consumption of poultry edibles. Adv. Anim. Vet. Sci., 3: 58-70.

Mathur, N. and A. Kumar, 2013. Physico-chemical characterization of industrial effluents contaminated soil of sanganer. J. Emerg. Trends Eng. Applied Sci., 4: 226-228.

Meagher, R.B., 2000. Phytoremediation of toxic elemental and organic pollutants. Curr. Opin. Plant Biol., 3: 153-162.

Nagajyoti, P.C., K.D. Lee and T.V.M. Sreekanth, 2010. Heavy metals, occurrence and toxicity for plants: A review. Environ. Chem. Lett., 8: 199-216.

Resongles, E., C. Casiot, R. Freydier, L. Dezileau, J. Viers and F. Elbaz-Poulichet, 2014. Persisting impact of historical mining activity to metal (Pb, Zn, $\mathrm{Cd}, \mathrm{Tl}, \mathrm{Hg}$ ) and metalloid (As, Sb) enrichment in sediments of the Gardon River, Southern France. Sci. Total Environ., 481: 509-521.

Sharma, R.K., M. Agrawal and F.M. Marshall, 2007. Heavy metal contamination of soil and vegetables in suburban areas of Varanasi, India. Ecotoxicol. Environ. Safe., 66: 258-266.

Sharma, R.K., M. Agrawal and F.M. Marshall, 2009. Heavy metals in vegetables collected from production and market sites of a tropical urban area of India. Food Chem. Toxicol., 47: 583-591.

Sherene, T., 2010. Mobility and transport of heavy metals in polluted soil environment. Biol. Forum: Int. J., 2: 112-121.

Singh, R.P. and M. Agrawal, 2007. Effects of sewage sludge amendment on heavy metal accumulation and consequent responses of beta vulgaris plants. Chemosphere, 67: 2229-2240.

Skinder, B.M., A.Q. Sheikh, A.K. Pandit and B.A. Ganai, 2014. Brick kiln emissions and its environmental impact: A review. J. Ecol. Natl. Environ., 6: 1-11.

Tahar, K. and B. Keltoum, 2011. Effects of heavy metals pollution in soil and plant in the industrial area, West ALGERIA. J. Korean Chem. Soc., 55: 1018-1023. 
Tammeorg, P., A. Simojoki, P. Makela, F.L. Stoddard, L. Alakukku and J. Helenius, 2014. Biochar application to a fertile sandy clay loam in boreal conditions: Effects on soil properties and yield formation of wheat, turnip rape and faba bean. Plant Soil, 374: 89-107.

Wang, Q.R., Y.S. Cui, X.M. Liu, Y.T. Dong and P. Christie, 2003. Soil contamination and plant uptake of heavy metals at polluted sites in China. J. Environ. Sci. Health. A Tox. Hazard. Subst. Environ. Eng., 38: 823-838.
Wani, H.S., S.G. Sanghera, H. Athokpam, J. Nongmaithem, R. Nongthongbam, S.B. Naorem and S.H. Athokpam, 2012. Phytoremediation: Curing soil problems with crops. Afr. J. Agric. Res., 7: 3991-4002.

Waoo, A.A., S. Khare and S. Ganguli, 2014. Extraction and analysis of heavy metals from soil and plants in the industrial area Govindpura, Bhopal. J. Environ. Hum., 1: 158-164. 